\section{Foreign bodies in dried mushrooms marketed in Italy}

\author{
Maria Rita Schiavo, ${ }^{1}$ Claudia Manno, \\ Antonina Zimmardi, ${ }^{1}$ Bruna Vodret, ${ }^{2}$ \\ Maria Giovanna Tilocca, ${ }^{2}$ \\ Serena Altissimi, ${ }^{3}$ Naceur M. Haouet ${ }^{3}$
}

${ }^{1}$ Institute for Experimental Veterinary

Medicine of Sicily, Palermo; ${ }^{2}$ Institute for

Experimental Veterinary Medicine of

Sardinia, Sassari; ${ }^{3}$ Institute for

Experimental Veterinary Medicine of

Umbria and Marche, Perugia, Italy

\section{Abstract}

The presence of foreign bodies in mushrooms affects their marketability and may result in health risks to consumers. The inspection of fresh or dried mushrooms today is very important in view of the increased consumption of this kind of food. Ten samples of dried mushrooms collected in supermarkets were examined for evidence of entomological contamination by macro and microscopic analytical methods, the so-called filth-test. A total of 4946 determinations, comprising $15 \mathrm{~g}$ of the vegetable matrix, were made. The microscopic filth test consistently detected an irregular distribution of physical contaminants following repeated determinations of the same sample. Visual examination, on the other hand, was not sufficient to ensure a product free of contaminants.

\section{Introduction}

In recent years a significant change in European consumers has been observed in food choice and consumption, both quantitatively and qualitatively. The development of this food market has stimulated official controls to implement policies in order to obtain modern standards to ensure the hygienic quality. A study supported by the Italian Ministry of Health has focused on hygienic quality of dried mushrooms, currently used in several food preparations for their taste, low calories and nutritious. Italy imports from other countries, both fresh and dried mushrooms; and Italian production of fresh edible mushrooms covers less than the $5 \%$ of the whole mushroom market. The remaining $95 \%$ of the product comes from non-EU countries in particular: East Europe and China (a leading trading partner in dried truffles too) and some stocks from Russia, South Africa and Morocco. Costs of production of these countries make them more competitive than Italy (National Italian companies select package and sell the imported dried production (Macrì, 2013; Rossi, 2014; Süss and Sitta, 2012).

The spontaneous growth of mushrooms is largely related to seasonal cycles and climatic conditions (temperature, generally between 15 and 25 degrees, accompanied by a certain degree of moisture in the soil). Once harvested, mushrooms will not maintain their freshness for prolonged time and need to be dried for later commercialization to maintain their quality and taste.

During its growth in the soil, mushrooms can often be parasitized by primary Diptera (larvae) infestation, most often belonging to the family Mycetophilidae. Other parasites reported to affect mushrooms during field production are: Muscidae, Sciaridae and Phoridae, which also affect the growth of mushrooms. Nevertheless, at the time of collection, larvae are already present inside the mushroom. During drying procedures larvae normally die, remaining within the slice and are visible in their small galleries inside the pulp or tramiti, which are full of carcasses of larvae (Locatelli et al., 2005). The presence and the number of larvae in the dried product depend on many factors including: size of the larva; thickness of the slices; humidity content in the fresh product and methods of drying. The Coleoptera, Collembola as well as mites from the soil can also parasitize fresh mushrooms; furthermore post-packaging infestation due to moths, mites, spiders and Formicidae can occur during the marketing phase (Locatelli, 1997).

In Italy the collection and marketing of epigeal mushrooms is regulated by specific regulations (Law of 23 August 1993, 352, and further modifications, MD of Trade and Industry and Handicraft of 10/09/1998; Italian Republic, 1993, 1998). Mushrooms follow are controlled by the same general regulations for health inspection on food and beverages issued by the European Community (called Hygiene Package; 2004) and Law 283/62 that prohibits the sale of food if invaded by parasites (Italian Republic, 1962). However, unlike the USA (defect action level/15 g: 20 larvae $<2$ $\mathrm{mm}$ or 5 larvae $>2 \mathrm{~mm}$ ) (FDA, 1998) and Canada (defect action level/15 g: 10-20 larvae $<2 \mathrm{~mm}$ or $0-5$ larvae $>2 \mathrm{~mm}$ ) (Government of Canada, 1999), current legislation in Italy does not indicate any tolerance limits concerning entomological contaminants such as the number and size of larvae and insects. The report on the Rapid Alert System for Food and Feed (RASFF, https://webgate.ec.europa.eu/rasffwindow/portal/) of the European Community governing food safety over the last decade concerned only n. 8 alerts due to infestation of insects and larvae in dried, frozen, pickled and fresh mushrooms from different countries (RASFF Portal). The requisitioning of food
Correspondence: Maria Rita Schiavo, Institute for Experimental Veterinary Medicine of Sicily, via Gino Marinuzzi 3, 90129 Palermo, Italy. Tel: +39.091 .6565306 - Fax: +39.091 .6565278$

E-mail: mariarita.schiavo@izssicilia.it

Key words: Mushroom; Larvae; Foreign bodies; Filth test; Food hygiene.

Acknowledgments: the present study was funded by the Italian Ministry of Health with Current Research IZS-SI 11/2011 entitled Hygiene Package: evaluation of analytical methods for the determination of solid impurities (filth test) in the regional chain products. Study of innovative techniques for the identification of impurities contaminants.

Received for publication: 8 July 2014 .

Revision received: 5 March 2015.

Accepted for publication: 5 March 2015

This work is licensed under a Creative Commons Attribution-NonCommercial 3.0 International License (CC BY-NC 3.0).

(C) Copyright M.R. Schiavo et al., 2015

Licensee PAGEPress, Italy

Italian Journal of Food Safety 2015; 4:4523

doi:10.4081/ijfs.2015.4523

stocks showing poor state of conservation, by the Health Authority, has increased considerably with over 75 tons of massively Diptera infested Chinese mushrooms of seized by the N.A.S. of Padua in 2009.

The presence of infesting species in mushrooms results in two direct consequences: i) affect the marketability of the product itself determining repugnance in the consumers; ii) represent a real heath risk due to allergic implication. It is proved that the ingestion of parasites or their contact (mites and insects or any part) can induce skin reactions and allergic symptoms including asthma (Van Lyndenvan Nes et al., 1996). The present study to detect foreign body contaminants in marketed, dried mushrooms was stimulated by several scientific reports which highlight the health risks such as respiratory allergies and panallergies linked to arthropods and their larvae, arachnids and crustaceans (Kagen and Kagen, 1990; Panzani and Ariano, 2001; La Grutta et al., 2011) known as panallergy. Finally, it is not negligible the particular immune susceptibility of allergic patients to different food allergens when they work in special sectors exposed to these kind of risks (Cimarra et al., 1999). The aim of this study was to provide updated data on the contamination of foreign bodies in different brands of dried mushrooms (Boletus spp) marketed in Italy using the filth test, which is a method to help safeguard the standard of hygiene of the food chain (Domenichini, 1997). 


\section{Materials and Methods}

Ten samples of dried edible mushrooms (Boletus spp.) bought in the supermarkets in Palermo (Italy), and made by different companies, were investigated in order to assess the presence of foreign bodies (including larvae and other impurities) using the filth test method, AOAC Official Method 967.24/B (Latimer, 2012). Each determination were performed by the complete rehydration of $15 \mathrm{~g}$ of the sample, trap off with heptane in Wildman trap flask and filtration through ruled filter paper. The filters (Whatman, 0858) were later observed under a stereomicroscope (Leica MZ 16A; Leica, Wetzlar, Germany) at different magnifications (30-100x) to identify solid impurities. Microscopic samples/fragments were eventually observed with an optical microscope (Leica DMR) at different magnification (10-20x).

\section{Results}

All the samples investigated were contaminated by biotic impurities such as larvae and their fragments, and whole insects and their fragments (beetles, spiders, mites and ants). The entomological contaminations were counted without any selection and classification. The non-organic impurities found in the samples were related to abiotic soil material.

Table 1 shows the total number of detected biotic and abiotic impurities in each determination, with respect to each sample. Table 2 shows for each sample, the place of packaging, number of determinations carried out (for a total of 46 determinations), average number of larvae (and parts of them) for each determination. Figure 1 shows some contaminants observed during trap off of the filth test.

\section{Discussion}

The results of this preliminary study confirmed reports by other authors relating to these products (Maroli et al., 2002, 2007): all epigeal mushrooms investigated showed natural and persistent primary infestation.

Most frequent parasites were Diptera larvae. The Diptera attack mushrooms during their growth: larvae eat the stem and cup during the growing season and die when drying procedures starts but their bodies remain within the fungus. If drying procedures are not adequately applied in the countries of origin (if too fast or too intensive), this will allow the persistence of the larvae inside the mushrooms, which normally are normally eliminat- ed when drying is properly performed.

It is clear that the visual examination carried out by producers on dried imported products, is not sufficient to guarantee a product free of arthropod contamination. The results of this study confirm that there is little secondary infestation of the products sold in Italy, demonstrating that local domestic industries possess adequate hygiene production standards (Pagani et al., 2012).

Application of the filth test and related microscopic observation represents accurate and easy to perform method for the identification of hidden contaminants. The critical point in the detection of physical contaminants is nearly always the large variability that it is observed in the distribution of impurities between the repeated determinations carried out on the same sample (Table 1). This variability is due to the fact this kind of the contaminants do not have a uniform distribution within the sample, thus resulting in the need to transform the data into values that can express a normal distribution; alternatively it may be necessary to increase the number of determinations in order to ensure a significant result. Another possibility is to utilize a prospective analysis applicable to production reality but this is difficult to implement in laboratories where analytical operations are performed routinely.

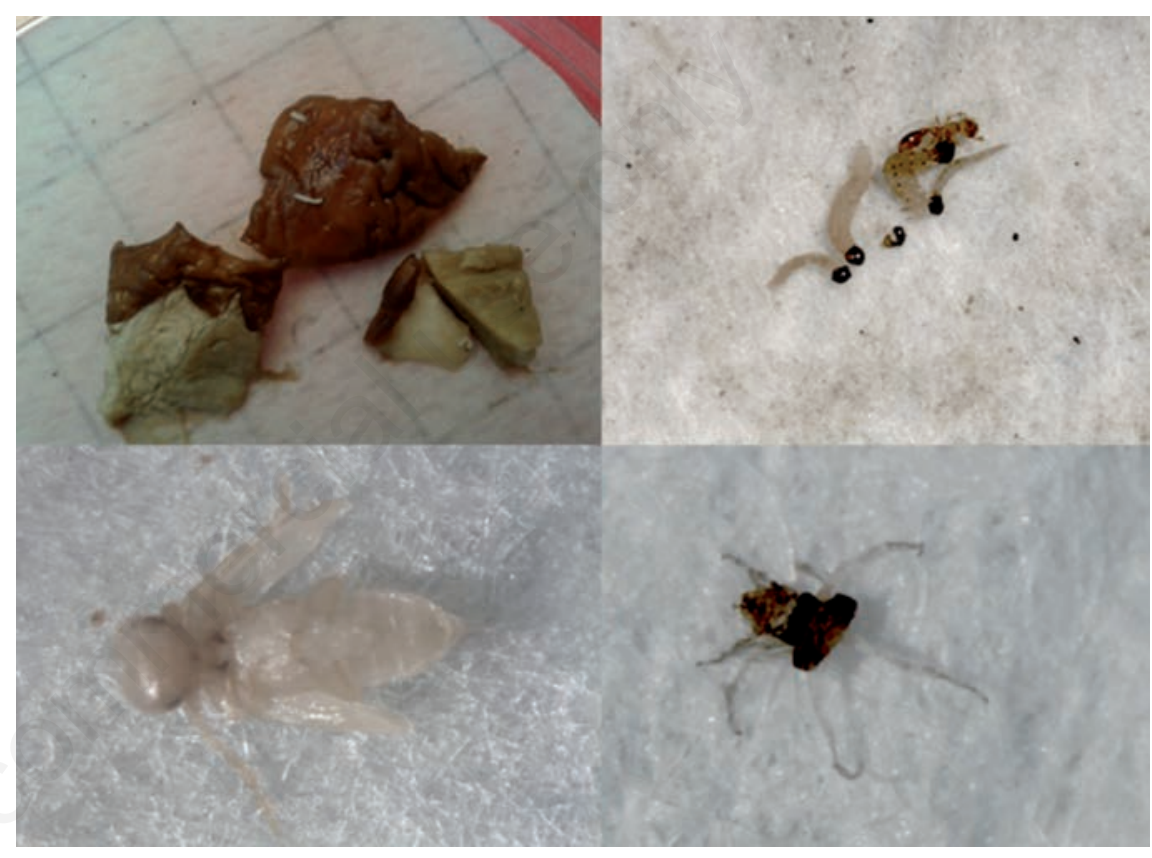

Figure 1. Entomological contaminations observed by filth-test analysis.

Table 1. Number of impurities (biotic and abiotic) recorded for each determination made on the sample.

\begin{tabular}{lcccccc} 
Sample (n) & $\mathbf{1}$ & $\mathbf{2}$ & $\mathbf{3}$ & $\mathbf{4}$ & 5 & 6 \\
\hline 1 & 24 & 20 & 31 & - & - & - \\
2 & 21 & 12 & 11 & 16 & 5 & - \\
\hline 3 & 13 & 22 & 33 & 1 & 0 & 1 \\
4 & 81 & 28 & 60 & 2 & 6 & 1 \\
\hline 5 & 45 & 69 & 123 & 3 & 10 & 14 \\
6 & 19 & 9 & 7 & - & - & - \\
\hline 7 & 10 & 13 & 16 & 4 & 2 & - \\
8 & 14 & 10 & 24 & 29 & - & - \\
\hline 9 & 6 & 41 & 30 & - & - & - \\
10 & 8 & 22 & 15 & 22 & 10 & - \\
\hline
\end{tabular}


Table 2. Samples were examined and identification data compared to the average value of the infestation entomatica.

\begin{tabular}{lccc} 
Sample n. & Origin/packaging & $\begin{array}{c}\text { Determination (n) } \\
(\text { total=46) }\end{array}$ & $\begin{array}{c}\text { Larvae/determination } \\
1\end{array}$ \\
2 & Gattatico & 3 & 16 \\
\hline 3 & Perugia & 5 & 11 \\
4 & Lecco & 6 & 10 \\
\hline 5 & Piacenza & 6 & 43 \\
6 & Bologna & 6 & 10 \\
\hline 7 & Viterbo & 3 & 9 \\
8 & Lecco & 5 & 19 \\
\hline 9 & Romania & 4 & 3 \\
10 & Catania & 3 & 5 \\
\hline
\end{tabular}

\section{Conclusions}

It should be noted, as pointed out by other authors (Maroli, 2012), the lack of legislation at national level needed to determine the critical points in these kind of products: i) the information on the label does not inform about the real origin of the product and their potential health risk: the consumer is not properly informed and can result in serious health hazards due to the presence of alien species and/or environmental contaminants and/or biological agents; ii) the lack of tolerance for the presence of parasites, indirectly influences the development of a control plan for physical contaminants over the massive import that this food has seen in recent years.

In spite of the natural infestation of the product only n. 8 notifications have been notified reported in the European Union (20012012) Rapid Alert System for Food and Feed (RASFF) Portal, indicating that the problem today is underestimated. The definition of the tolerance limits in Italy, perhaps through an initial approving/adoption of the American standards, would have a double positive effect: a strong implementation in surveillance/control in this sector, greater visibility for food companies if better qualified for respect of health of their consumers.

\section{References}

Cimarra M, Martìnez- Còcera C, Chamarro M, Cabrera M, Robledo T, Lombardero M, Alonso A, Castellano A, Bartolome JM, 1999. Occupational asthma caused by champignons flies. Allergy 54:521-5.

Domenichini G, 1997. Impurità solide negli ali- menti (filth test). Chiriotti, Pinerolo, Italy. European Commission, 2004. Hygiene package. Available from: http://ec.europa.eu/ ood/food/biosafety/hygienelegislation/com m_rules_en.htm

FDA, 1998. Food defect action levels. Department of Health and Human Service, Public Health Service, Food and Drug Administration, Center for Food Safety and Applied Nutrition, Washington, DC, USA.

Government of Canada, 1999. Health protection branch guidelines for the general cleanliness of food. An overview. Government of Canada, Ottawa, Canada.

Italian Republic, 1962. Regulation of the Italian Republic of 30 April 1962: Disciplina igienica della produzione e della vendita delle sostanze alimentari e delle bevande, 283. In: Official Journal, L 139, 04/06/1962.

Italian Republic, 1993. Regulation of the Italian Republic of 23 August 1993: Norme quadro in maniera di raccolta e commercializzazione dei funghi epigei freschi e conservati, 352. In: Official Journal, L 215, 13/09/1993.

Italian Republic, 1998. Regulation of the Italian Republic of 9 October 1998: Menzioni qualificative che accompagnano la denominazione di vendita dei funghi secchi. In: Official Journal, L 249, 24 October 1998. arthropods. Insects, arachnids, and crustaceans. Clin Rev Allerg 8:99-125.

La Grutta S, Calvani M, Bergamini M, Pucci N, 193Asero R, 2011. Allergia alla Tropomiosina: dalla diagnosi molecolare alla pratica clinica. Available from: http://www.siaip.it/upload/riap/415_Allergi a\%20alla\%20Tropomiosina.pdf

Latimer GW, 2012. Official methods of analysis of AOAC international, $19^{\text {th }}$ ed. AOAC,
Kagen SL, Kagen SL, 1990. Inhalant allergy to
Gaithersburg, MA, USA.

Locatelli DP, 1997. Funghi conservati. In: Domenichini G, ed. Atlante delle impurità solide negli alimenti. Chiriotti, Pinerolo, Italy, pp 122-31.

Locatelli DP, Süss L, Trevisan A, 2005. Ditteri fungivori in funghi essiccati. Ind Aliment 44:250-5.

Macrì A, 2013. Origine dei funghi. Available from: http://www.sicurezzalimentare.it /index.php/origine-dei-funghi/

Maroli M, Khoury C, Bianchi R, Aureli P, 2002. Considerazioni sui livelli di contaminazione entomatica dei funghi secchi attualmente in commercio in Italia. In: Proceedings of the 7th Simposium La difesa antiparassitaria nelle industrie alimentari e la protezione degli alimenti, 18-20 September, Piacenza, Italy, pp 462-71.

Maroli M, Khoury C, Bianchi R, 2007. Funghi secchi e contaminazioni entomatiche di campo: metodiche di analisi e prospettive per la definizione di livelli igienici di accettabilità. In: Cravedi P, ed. Proceedings of the 8th Simposium La difesa antiparassitaria nelle industrie alimentari e la protezione degli alimenti, 26-28 September, Piacenza, Italy, pp 142-50.

Maroli M, 2012. La contaminazione entomatica nella filiera degli alimenti di origine vegetale: controllo igienico sanitario e limiti di tolleranza. Available from: www.accademiaentomologia.it/rendiconti/2011/03f\%20 Maroli.pdf

Pagani M, Nicoli Aldini R, Cravedi P, 2012. Analisi entomologiche degli alimenti: risultati di un decennio di attività. In: Proceedings of the 9th Simposium La difesa antiparassitaria nelle industrie alimentari e la protezione degli alimenti, 19-21 September, Piacenza, Italy, pp 385-91.

Panzani RC, Ariano R, 2001. Arthropods and invertebrates allergy (with the exclusion of mites): the concept of panallergy. Allergy 56(Suppl.69):1-22.

Rossi G, 2014. Sito tecnici della prevenzione ispettori micologici. Available from: http:/www.ispettorimicologi.it

Süss L, Sitta N, 2012. Gli artropodi fungicoli: presenza, frequenza e impatto nei funghi spontanei freschi, secchi e conservati destinati all'alimentazione umana. In: Proceedings 5th International Congress on Micotossicology, Milan, 3-4 December 2012, pp 14-15.

Van Lynden-van Nes AMT, Koren LGH, Snijders MCL, Van Bronswijk JEMH, 1996. Medical impact of arthropod allergens. In: Wildey $\mathrm{KB}$, ed. Proceedings of the Second International Conference on Urban Pests, Edinburgh, Scotland, pp 17-30. 